\title{
MAKNA TAGLINE 'MENJADI YANG TERBAIK' IKLAN TELKOMSEL VERSI PILOT PAPUA RIKO KABAK
}

\section{The Meaning Of Tagline 'Menjadi Yang Terbaik' Telkomsel Advertising Version Papua Pilot Riko Kabak}

\author{
Juhari Tianotak, Nur Aini Shofiya Asy'ari \\ Ilmu Komunikasi, Universitas Darussalam Gontor \\ Diterima 05 Januari 2019/ Disetujui 29 Maret 2019
}

\begin{abstract}
Corporate identity is an effort to create a corporate identity that is fully implemented through corporate communication activities to customers that can be done in several ways, one of them is advertising. In creating an ad, a tagline is needed so that consumers easily remember the contents of the message and have the distinguishing power of the advertisements supported. Usually, the ad tagline is created to reflect a recognized company profile. Telkomsel carries the tagline of Being the Best through several advertisements it produces, one of the versions of the Papua Pilot, Rico Kabak. As a communication product, advertisements have certain messages that are conveyed through narration and visualization. This research tries to interpret the meaning of the tagline to be the best Telkomsel advertisement for the Papua Pilot Riko Kabak version. The interpretation of the meaning of advertising is obtained by analyzing the data previously collected through the process of documentation, observation, and literature. Meaning analysis is done by using Roland Barthes's semiotic analysis. The results of advertising carried out gather interpretations of meaning Being the best is a business association of a person in carrying out tasks based on sincerity, concern, struggle, responsibility, strength, alertness, sacrifice, and dedication or self-service. The results of this study are expected to contribute to the study of message content analysis using Roland Barthes's semiotic study.
\end{abstract}

Keywords; Advertising, Telkomsel, Tagline, Semiotics

\begin{abstract}
ABSTRAK
Corporate identity yang merupakan usaha untuk menciptakan identitas diri perusahaan secara konsisten dilaksanakan melalui kegiatan komunikasi perusahaan terhadap konsumen yang dapat dilakukan dengan beberapa cara, salah satunya dengan iklan. Dalam membuat sebuah iklan dibutuhkan sebuah tagline agar konsumen mudah mengingat isi pesan iklan dan mempunyai daya pembeda dari iklan-iklan pesaingnya. Biasanya, tagline iklan dibuat untuk mencerminkan profil perusahaan yang bersangkutan. Telkomsel mengusung tagline Menjadi Yang Terbaik melalui beberapa iklan yang diproduksinya, salah satunya versi Pilot Papua Riko Kabak. Sebagai produk komunikasi, iklan memiliki pesan-pesan tertentu yang disampaikan melalui narasi dan visualisasi. Penelitian ini bertujuan untuk mengintepretasikan makna tagline Menjadi Yang Terbaik Iklan Telkomsel versi Pilot Papua Riko Kabak. Intepretasi makna iklan didapatkan dengan menganalisa datadata yang sebelumnya dikumpulkan melalui proses dokumentasi, observasi dan studi pustaka. Analisa makna dilakukan dengan menggunakan analisis semiotika Roland Barthes. Hasil analisa iklan yang dilakukan melahirkan intepretasi bahwa makna Menjadi Yang Terbaik adalah adalah sebuah kesatuan usaha seseorang dalam melaksanakan sebuah tugas yang didasari kesungguhan, kepedulian, perjuangan, tanggung jawab, keberanian, kesigapan, pengorbanan dan dedikasi atau pengabdian diri. Hasil penelitian ini diharapkan dapat berkontribusi terhadap kajian analisis isi pesan terutama yang menggunakan kajian semiotika Roland Barthes.

Kata Kunci; Iklan, Telkomsel, Tagline, Semiotics
\end{abstract}

*Korespondensi Penulis:

E-mail: nurainishofia@unida.gontor.ac.id 


\section{PENDAHULUAN}

Iklan merupakan suatu bentuk komunikasi non-personal melalui beragam media yang dibayar oleh perusahaan, organisasi non-profit dan individu-individu dengan menggunakan pesan iklan yang diharapkan dapat menginformasikan atau membujuk kalangan tertentu yang mendengar dan melihat iklan tersebut. Menurut PPPI (Persatuan Perusahaan Periklanan Indonesia) "Periklanan adalah segala bentuk pesan terhadap suatu produk yang disampaikan melalui suatu media, dibiayai oleh pemrakarsa dan ditunjukkan kepada sebagian atau seluruh masyarakat" (Tamburaka, 2013).

Iklan dan promosi menjadi suatu bagian yang tak dapat dipisahkan dalam dunia bisnis. Di era globalisasi seperti sekarang ini, iklan telah menjadi suatu komunikasi yang sangat penting tidak saja bagi produsen barang dan jasa tetapi juga bagi para konsumen. Kemampuan iklan dan metode promosi lainnya dalam menyampaikan pesan kepada para konsumennya menjadikan kedua bidang tersebut memiliki peran yang penting bagi suatu perusahaan atau para penjual jasa. Iklan dan promosi yang dilakukan bukan hanya pada media cetak dan elektronik, tetapi memasuki era globalisasi seperti ini banyak produsen yang memilih untuk beriklan dan melakukan promosi pada new media yaitu youtube.

Menurut Tamburaka (2013) Iklan menggunakan banyak elemen didalamnya untuk mempengaruhi indra pendengaran dan penglihatan manusia. Inilah yang menjadi daya tarik iklan sehingga orang bersedia membeli produk yang diiklankan. Elemen suara, yaitu melalui kata-kata yang ada pada iklan tersebut agar pesan yang terdapat dalam iklan tersebut dapat dimengerti. Tidak hanya itu, penggunaan musik dalam iklan juga untuk menambah nuansa indahnya suara iklan itu sendiri. Elemen lain adalah gerakan dan gambar dalam iklan, gerakan dan gambar dalam iklan dibuat sedemikian rupa agar mampu menarik perhatian dengan menggunakan model artis dengan gerakan-gerakan badan tertentu sehingga terlihat menarik.

$$
\text { Menurut Morissan (2010), }
$$

sebagaimana yang dituliskan di dalam bukunya yang berjudul periklanan: komunikasi pemasaran terpadu menjelaskan, iklan di media massa dapat digunakan untuk menciptakan citra merek (brand image) dan daya tarik simbolis bagi suatu perusahaan atau merek. Hal ini menjadi sangat penting khususnya bagi produk yang sulit dibedakan dari segi kualitas maupun fungsinya dengan produk saingannya dan pemasang iklan harus dapat memanfaatkan iklan di media massa untuk memposisikan produknya di mata konsumen.

Dalam Kamus Istilah Periklanan Indonesia, corporate identity adalah unsur desain yang digunakan oleh perusahaan maupun lembaga periklanan lainnya untuk menciptakan identitas diri yang konsisten dan dapat dikenal melalui kegiatan komunikasi, promosi, dan distribusi bahan. Apabila dilihat dari pengertian diatas, maka slogan atau tagline yang terdapat dalam suatu iklan juga termasuk dalam identitas perusahaan.

Tagline merupakan suatu urutan katakata atau suku kata pendek yang ekspresif yang digunakan untuk mengkomunikasikan dan mendramatisir manfaat-manfaat fungsional dan emosional dari brand bagi para pelanggan dan pelanggan potensial dalam usaha untuk memengaruhi perasaan konsumen terhadap brand tersebut (Knapp, 2001). Perusahaan menggunakan tagline untuk mengkomunikasikan tujuan sebuah merek dan menunjukkan citra dirinya pada khalayak. Tagline mengkomunikasikan perbedaan dirinya dengan kompetitornya. Tagline biasanya dikenalkan melalui Abovethe Line(ATL) yaitu dengan menayangkan iklan di berbagai media baik media massa, cetak maupun elektronik (Susanto \& Wijanarko, dalam Zulianto, 2004) untuk tujuan dari penggunaan tagline.

Tagline ini bisa berubah sesuai dengan perubahan situasi dan kondisi, maupun sebagai strategi agar konsumen tidak bosan. Dari definisi diatas dapat ditarik kesimpulan bahwa tagline adalah bagian dari iklan yang biasa digunakan sebagai penutup pesan agar konsumen mudah mengingat isi pesan iklan dan mempunyai daya pembeda dari iklan-iklan pesaingnya.

Telkomsel adalah salah satu perusahaan operator telekomunikasi terbaik dan memiliki jaringan terluas di Indonesia. Sebagaimana yang dikatakan Heru Sutadi seorang pengamat teknologi informatika (TI) 
kepada validnews.com (27 September 2017). Menurutnya, provider pemenang yang memiliki pelanggan terbesar itu selalulah pihak yang memiliki jaringan yang sangat luas dibandingkan pesaingnya. Ucapannya itu memang merujuk pada kelebihan operator Telkomsel milik BUMN yang memiliki jaringan luas hingga ke plosok-plosok. Hal ini disebabkan karena Telkomsel memiliki base transceiver station (BTS) merata hingga plosok-plosok daerah di Indonesia.

Saat ini, setiap operator yang ada di Indonesia sedang mempromosikan jaringan internet 4G LTE. 4G merupakan singkatan dari Fourth Generation Technology. Mengutip Wikipedia, istilah ini mengacu kepada standar generasi keempat dari teknologi telepon seluler. 4G merupakan pengembangan dari teknologi $3 \mathrm{G}$ dan $2 \mathrm{G}$. Sistem 4G menyediakan solusi internet protocol (IP) yang konprehensif dimana suara, data dan arus multimedia dapat sampai kepada pengguna kapan saja dan dimana saja, pada rata-rata data lebih tinggi dari generasi sebelumnya.

Direktur utama Telkomsel Ririek Ardiansyah juga mengatakan Telkomsel telah lebih dulu mengoperasikan jaringan 4G LTE (Long Term Evolution) di frekuensi $900 \mathrm{MHz}$ dan $1800 \mathrm{MHz}$. frekuensi $2300 \mathrm{MHz}$ lebih bersifat sebagai tambahan untuk meningkatkan kenyamanan pengguna. Kalaupun handset tidak mendukung, pengguna masih bisa tersambung ke band 4G lain yang dioperasikan Telkomsel. Hal ini dikarenakan Telkomsel memenangkan pelelangan spektrum ekstra selebar $30 \mathrm{MHz}$ di frekuensi $2300 \mathrm{MHz}$ dan akan dipakai untuk meningkatkan kualitas layanan 4G LTE (https://tekno.kompas .com, pada 24 Okt 2017, 11.01, (diakses pada 6 April 2018, 08.50)

Kini operator seluler yang ada di Indonesia berlomba-lomba mempromosikan dan mengiklankan program yang mereka tawarkan terkait 4G LTE melalui media massa seperti televisi, koran, radio dan lainnya, tak terkecuali Telkomsel, Telkomsel yang menjadi operator seluler terbaik di Indonesia dan menduduki peringkat keenam di dunia,kini telah mengiklankan program 4G LTE tersebut. Dalam mengiklankan program 4G LTE, Telkomsel menggunakan tagline "Menjadi yang Terbaik", tercatat terdapat 9 iklan yang ditayangkan Telkomsel dengan menggunakan tagline tersebut. Diantara iklan-iklan tersebut yaitu iklan Telkomsel broadband 4G LTE versi Pilot Papua Kapten Riko Kabak.

Iklan versi pilot Papua menceritakan seorang anak bangsa yang berusaha menjadi yang terbaik untuk tanah kelahirannya. Sosok ini bernama Riko Kabak. Ia sadar hanya pesawat yang menjadi alat transportasi utama antara pulau di Papua, dan itulah yang menjadi alasan utama untuk menjadi yang terbaik. Sebagai pilot, Riko selalu memastikan masyarakat di berbagai wilayah di Papua mendapatkan kebutuhan mereka. Dalam bekerja di sebuah maskapai penerbangan, komunikasi lancar dan informasi terkini setiap hari adalah hal yang diperlukan. Namun hal tersebut tidak menjadi kendala karena sinyal Telkomsel menjangkau hingga ke daerah paling timur Indonesia. Dengan jaringan yang terbesar hingga ke pelosok negeri, Telkomsel telah menghubungkan Indonesia dengan layanan telekomunikasi, yang membuka berbagai kesempatan baru dan mendorong dampak sosial ekonomi yang positif kepada masyarakat.

Untuk menjadi yang terbaik bukanlah hal yang mudah, dibutuhkan perjuangan seperti yang dilakukan oleh Kapten Riko Kabak yang berjuang untuk membantu tanah kelahirannya. Perjuangan tersebut akan dilakukan dengan dorongan semangat yang kuat yang berasal dari dalam diri, sebagaimana semangat yang dicontohkan oleh Dokter Anggrawati dalam iklan diatas untuk selalu membuka wawasannya meski dokter tersebut tinggal di daerah pedalaman.

Iklan Telkomsel tersebut menarik untuk dikaji karena menyuguhkan konsep yang berbeda dengan iklan-iklan telekomunikasi yang lainnya. Iklan Telkomsel tersebut juga menberikan prespektif menjadi yang terbaik, karena setiap orang memiliki prepektif yang berbeda-beda mengenai hal ini. Terdapat banyak nilai-nilai positif dalam kehidupan manusia. Bukan hanya itu, iklan ini juga menyimpan simbol-simbol yang bisa dikaji dengan menggunakan metode semiotika.

Jika berbicara tentang iklan, tentu pesannya akan muncul melalui tanda verbal maupun visual. Melalui tanda verbal dan tanda visual tersebut lahirlah makna pesan. Untuk memahami makna apa yang lahir dalam tanda- 
tanda (signs) dan simbol-simbol (symbols) dalam iklan, diperlukan suatu analisis yang mendalam dengan menggunakan alat analisis yang sesuai. Kajian ilmu yang paling tepat untuk menganalisisnya ialah semiotika.

Semiotika adalah ilmu tanda yaitu metode analisa untuk mengkaji tanda. Tandatanda adalah perangkat yang kita pakai dalam upaya mencari jalan di dunia ini. Di tengahtengah manusia dan bersama-sama manusia. Tanda terletak di mana-mana, kata adalah tanda, demikian pula gerak isyarat. Tanda dalam pengertian ini bukanlah hanya sekedar harfiah melainkan lebih luas misalnya struktur karya sastra, struktur film, bangunan, nyanian burung, dan segala sesuatu yang dianggap sebagai tanda dalam kehidupan manusia (Kaelan, 2017). Maka penelitian ini bermaksud untuk menganalisa makna tagline Menjadi yang Terbaik melalui analisis semiotika iklan Telkomsel versi Pilot Papua Riko Kabak.

\section{METODE PENELITIAN}

Penelitian ini menggunakan analisis semiotika yang merupakan teknik penelitian bagi kajian komunikasi yang cenderung lebih banyak mengarah pada sumber maupun penerimaan pesan. Dikategorikan kedalam penelitian interpretatif dan subjektif karena penelitian ini mengandalkan kemampuan peneliti dalam menafsirkan teks ataupun tanda yang dikaitkan dengan nilai-nilai ideologi, budaya, moral dan spiritual. Maka peneliti melakukan analisis yang mengarah pada intepretasi-intepretasi alternatif. Penelitian ini menggunakan penyajian data secara terstruktur serta memberikan gambaran terperinci objek penelitian beberapa pesan komunikasi dalam bentuk tanda-tanda.

Analisis semiotika yang digunakan mengacu pada semiologi Roland Barthes signifikasi dua tahap (two order signification); denotasi dan konotasi. Semiologi Roland Barthes dipilih karena mampu memaknai tanda pada media visual seperti iklan televisi. Semiologi Roland Barthes menekankan pada peran pembaca (reader), peran di sini berarti walaupun sebuah tanda telah memiliki makna denotasi ataupun konotasi, tetapi tetap saja dibutuhkan keaktifan pembaca agar dapat berfungsi. Dalam semiologi Roland Barthes, kode-kode komunikasi yang terdapat pada desain iklan televisi nantinya akan dicari makna riil-nya (denotasi), kemudian hubungan antara satu tanda dengan tanda lainnya akan dicari.

Pada dasarnya objek penelitian adalah sifat keadaan dari suatu benda, orang atau yang menjadi pusat perhatian dan sasaran penelitian. Objek dari penelitian ini adalah iklan Telkomsel broadband 4G LTE versi Pilot Papua Kapten Riko Kabak dan Dokter Anggarwati yang ditayangkan di televisi sebagai iklan audio visual. Iklan ini tayang disela-sela acara televisi, seperti sinetron, berita ataupun talk show. Iklan Telkomsel versi Pilot Papua Kapten Riko Kabak pertama kali di upload di youtube pada tanggal 28 September 2017 sedangkan iklan Telkomsel versi Dokter Anggarwati pertama kali di upload di youtube pada tanggal 12 Mei 2017, kedua iklan ini memiliki durasi waktu yang sama yaitu satu menit.

Observasi dipahami sebagai suatu pengamatan langsung terhadap objek untuk mengetahui kebenaran, situasi, kondisi, konteks, ruang serta maknanya dalam rangka pengumpulan data suatu penelitian. Maka dalam penelitian ini, observasi juga dilakukan dengan pengumpulan data yang memanfaatkan keseluruhan pancaindra untuk mengamati dan memahami sebuah realitas, yaitu dengan cara mengamati secara langsung iklan Telkomsel versi pilot Papua Kapten Riko Kabak.

Dokumentasi adalah sekumpulan berkas yang digunakan untuk mencari data mengenai hal-hal yang berupa catatan, transkrip, buku, surat kabar, majalah, agenda dan sebagainya. Pada penelitian ini dokumentasi dilakukan dengan cara mencari data dan hal-hal yang berkaitan dengan iklan Telkomsel broadband 4G LTE versi Pilot Papua Kapten Riko Kabak dan versi Dokter Anggrawati melalui internet dan buku-buku yang berkaitan dengan penelitian ini.

Untuk menganalisa data, peneliti menggunakan metode analisis semiotika dengan mempertimbangkan beberapa hal penting; yaitu Penanda dan petanda, Gambar, indeks dan symbol, Fenomena sosiologi (demografis orang didalam iklan dan orangorang yang menjadi sasaran iklan, refleksi kelas sosial ekonomi, gaya hidup dan sebagainya), Sifat daya tarik yang dibuat untuk 
menjual produk, melalui naskah dan orangorang yang dilibatkan didalam iklan, design dari iklan, termasuk tipe perwajahan yang digunakan, warna dan unsur estetika yang lain, publikasi yang ditemukan di dalam iklan, dan khalayak yang diharapkan oleh publikasi tersebut. Dalam menganalisa iklan Telkomsel 4G LTE versi pilot Papua Kapten Riko Kabak, peneliti akan membagi iklan tersebut menjadi beberapa potongan kata-kata dan gambar dengan membuat story board atau story line dari iklan tersebut. Kemudian peneliti akan menganalisa dan mendeskripsikan potongan gambar-gambar tersebut di dalam story board sehingga dapat diketahui citra merek (brand image) apa yang ingin dibentut Telkomsel sebagai operator seluler terbaik melalui analisa isi pesan kedua iklan televisi diatas.

\section{HASIL DAN PEMBAHASAN}

Analisis Isi Pesan Iklan Versi Pilot Papua Riko Kabak.

\begin{tabular}{|c|c|c|}
\hline \multicolumn{3}{|c|}{ Adegan 1 (Scene 1) } \\
\hline Visual & Dialog/Monolog & Type of shoot \\
\hline & Ngoeng... (Suara pesawat) & Extreme long shoot \\
\hline & "Angin kencang, & Medium shoot \\
\hline & cuaca ekstrim, pegunungan tinggi, & Long shoot \\
\hline & adalah hal yang harus saya hadapi" & Medium shoot \\
\hline Denotasi & Konotasi & Mitos \\
\hline $\begin{array}{c}\text { Pada scene ini menampilkan suatu } \\
\text { pesawat yang terbang melintasi } \\
\text { pegunungan. Scene ini juga } \\
\text { menampilkan keadaan cuaca yang } \\
\text { extrim dan diiringi dengan angin } \\
\text { kencang yang sering terjadi dan } \\
\text { juga menampilkan keadaan pilot } \\
\text { ketika menghadapi cuaca yang } \\
\text { buruk. }\end{array}$ & $\begin{array}{c}\text { Pesawat yang terbang melintasi } \\
\text { pegunungan menjelaskan bahwasanya } \\
\text { Papua memang memiliki banyak } \\
\text { pegunungan yang tinggi dan akses } \\
\text { tercepat untuk mencapai suatu daerah } \\
\text { terpencil di Papua hanya dengan } \\
\text { menggunakan pesawat terbang. } \\
\text { Selain itu, monolog angin kencang, } \\
\text { cuaca ekstrim, pegunungan tinggi } \\
\text { yang terdapat pada scene ini } \\
\text { menggambarkan akan perjuangan dan } \\
\text { keberanian Kapten Riko dalam } \\
\text { menghadapi setiap rintangan. } \\
\end{array}$ & $\begin{array}{l}\text { Sebagian masyarakat berpendapat bahwa } \\
\text { kondisi dan keadaan yang tidak baik dapat } \\
\text { menghambat niat baik seseorang. Tetapi } \\
\text { iklan ini menekankan bahwasanya apabila } \\
\text { niat baik itu ada dan didorong oleh tekad } \\
\text { yang kuat maka kondisi dan keadaan yang } \\
\text { tidak baik tidak akan menjadi penghambat } \\
\text { untuk mengerjakan niat baik tersebut. Hal } \\
\text { tersebut digambarkan dengan keadaan } \\
\text { Kapten Riko yang harus menghadapi angin } \\
\text { kencang, cuaca ekstrim dan pegunungan } \\
\text { yang tinggi untuk mengantarkan bantuan ke } \\
\text { daerah terpencil yang ada di Papua }\end{array}$ \\
\hline
\end{tabular}

Gambar 1: Screenshot Iklan Telkomsel "Menjadi yang Terbaik" versi Pilot Papua, scene 1

Sumber : Olahan Peneliti 
Angin kencang, cuaca ekstrim dan pegunungan tinggi pada scene ini menggambarkan akan rintangan yang harus dihadapi Riko kabak sebagai seorang pilot. Hal ini diperjelas dengan monolog pada scene ini "angin kencang, cuaca ekstrim, pegunungan tinggi, adalah hal yang harus saya hadapi". Monolog tersebut menjadi tanda akan perjuangan dan keberanian Kapten Riko dalam menghadapi segala rintangan. Angin yang kencang dan cuaca yang buruk yang terdapat pada visual dalam scene ini juga menggambarkan perjuangan dan keberanian Telkomsel dalam menghadapi rintangan. Karena angin yang kencang dan cuaca yang buruk dapat mempengaruhi jaringan internet yang dipancarkan oleh Telkomsel, begitu juga dengan pegunungan yang tinggi. Semua rintangan harus dihadapi oleh Telkomsel sebagai operator seluler terbaik di Indonesia.

Visual terakhir ketika Kapten Riko harus menghadapi angin dan cuaca yang ekstrim pada scene ini dan monolog "adalah hal yang harus saya hadapi" juga merupakan tanda akan kesungguhan Kapten Riko Kabak dalam melakukan profesinya sebagai seorang pilot. Visual ini diambil dengan medium shoot untuk lebih memperjelas akan keberanian dan kesungguhan Kapten Riko dalam menerbangkan pesawatnya ketika cuaca sedang buruk.

\begin{tabular}{|c|c|c|}
\hline \multicolumn{3}{|c|}{ Adegan 2 (Scene 2) } \\
\hline Visual & Dialog/Monolog & Type of shoot \\
\hline & "Inilah saya. & Medium shoot \\
\hline & $\begin{array}{l}\text { Mengerahkan kemampuan saya } \\
\text { kepada Papua lewat udara. }\end{array}$ & Extreme long shoot \\
\hline & & Long shoot \\
\hline Denotasi & Konotasi & Mitos \\
\hline $\begin{array}{c}\text { Pada scene ini menampilkan } \\
\text { seorang pilot Papua yang } \\
\text { bernama Kapten Riko Kabak } \\
\text { yang sedang menerbangkan } \\
\text { pesawatnya. Pada scene ini juga } \\
\text { menampilkan pesawat yang akan } \\
\text { mendarat diatas landasan yang } \\
\text { hanya sekedar tanah lapang yang } \\
\text { becek. }\end{array}$ & $\begin{array}{c}\text { Sosok Kapten Riko Kabak dan } \\
\text { pesawat terbang yang di tampilkan } \\
\text { pada scene ini mewakili akan } \\
\text { kesungguhan Kapten Riko dalam } \\
\text { mengerahkan kemampuannya untuk } \\
\text { membantu mengirimkan bantuan } \\
\text { kepada masyarakat Papua yang tinggal } \\
\text { di daerah pedalaman dengan } \\
\text { keahliannya menerbangkan pesawat } \\
\text { terbang, sebagai bentuk dari } \\
\text { pengabdiannya kepada Papua. }\end{array}$ & $\begin{array}{l}\text { Kebanyakan masyarakat hanya mengetahui } \\
\text { bahwasanya pesawat hanya bisa mendarat } \\
\text { diatas landasan yang rata dan beraspal. } \\
\text { Tetapi iklan ini memberikan pengetahuan } \\
\text { kepada kita bahwasanya pesawat juga bisa } \\
\text { mendarat diatas landasan yang masih } \\
\text { terbuat dari tanah dan bergelombang. } \\
\text { Landasan yang seperti ini yang akan } \\
\text { menjadi tantangan tersendiri bagi pilot } \\
\text { yang menegendalikan pesawat tersebut. }\end{array}$ \\
\hline
\end{tabular}

Gambar 2 : Screenshot Sumber Iklan Telkomsel "Menjadi yang Terbaik" versi Pilot Papua, Scene 2

Sumber : Olahan Peneliti 
Teknik pengambilan gambar pada visual pertama dalam scene ini diambil dengan cara medium shoot untuk memperkenalkan seorang pilot yang bernama Kapten Riko Kabak yang menjadi aktor utama dalam iklan ini melalu visual yang bertuliskan nama dan profesi, dan juga monolog "inilah saya. Mengerahkan kemampuan saya kepada Papua lewat udara”. Monolog ini menjadi tanda akan kesiapan Kapten Riko untuk mengabdikan diri kepada masyarakat Papua dengan keahliannya sebagai seorang pilot. Visual dan monolog ini menggambarkan kesiapan Telkomsel untuk mengabdikan diri kepada masyarakat yang tinggal di daerah pedalaman dengan memperluas jaringan internet 4G LTE yang bisa diakses hingga ke daerah pedalaman Papua, sehingga masyarakat Papua dapat terbantu dengan adanya jaringan internet tersebut, karena Papua merupakan pulau yang terletak di timur Indonesia dengan pegunungan yang tinggi dan akses jalan yang kurang begitu baik.

Jika dilihat dari ekspresi wajah Kapten Riko pada scene ini, menandakan akan kesungguhannya untuk mengabdikan diri kepada masyarakat Papua. Kesungguhan tersebut tentunya di dorong oleh niat dan tekad yang kuat untuk mengabdikan diri. Niat dan tekad merupakan dua kata yang memiliki makna yang berbeda. Dalam KBBI online niat adalah maksud atau tujuan suatu perbuatan atau bisa juga diartikan kehendak. Sedangkan tekad adalah kemauan atau kehendak yang pasti atau bisa juga diartikan sebagai kebulatan hati. Jadi niat merupakan kehendak atau kemauan untuk melakukan sesuatu, tetapi tekad lebih cenderung kepada ketetapan hati atau komitmen untuk melakukan sesuatu. Maka dari niat dan tekad yang kuat itulah timbul kesungguhan dalam diri Kapten Riko untuk mengabdikan dirinya sebagai seorang pilot kepada masyarakat yang tinggal di daerah Papua. Telkomsel juga ingin menunjukkan kesungguhannya untuk mengabdikan diri kepada masyarakat Indonesia sebagai perusahan operator telekomunikasi yang terbaik di Indonesia.

Visual kedua dan ketiga dalam scene ini diambil dengan cara extreme long shoot dan long shoot. Kedua teknik pengambilan

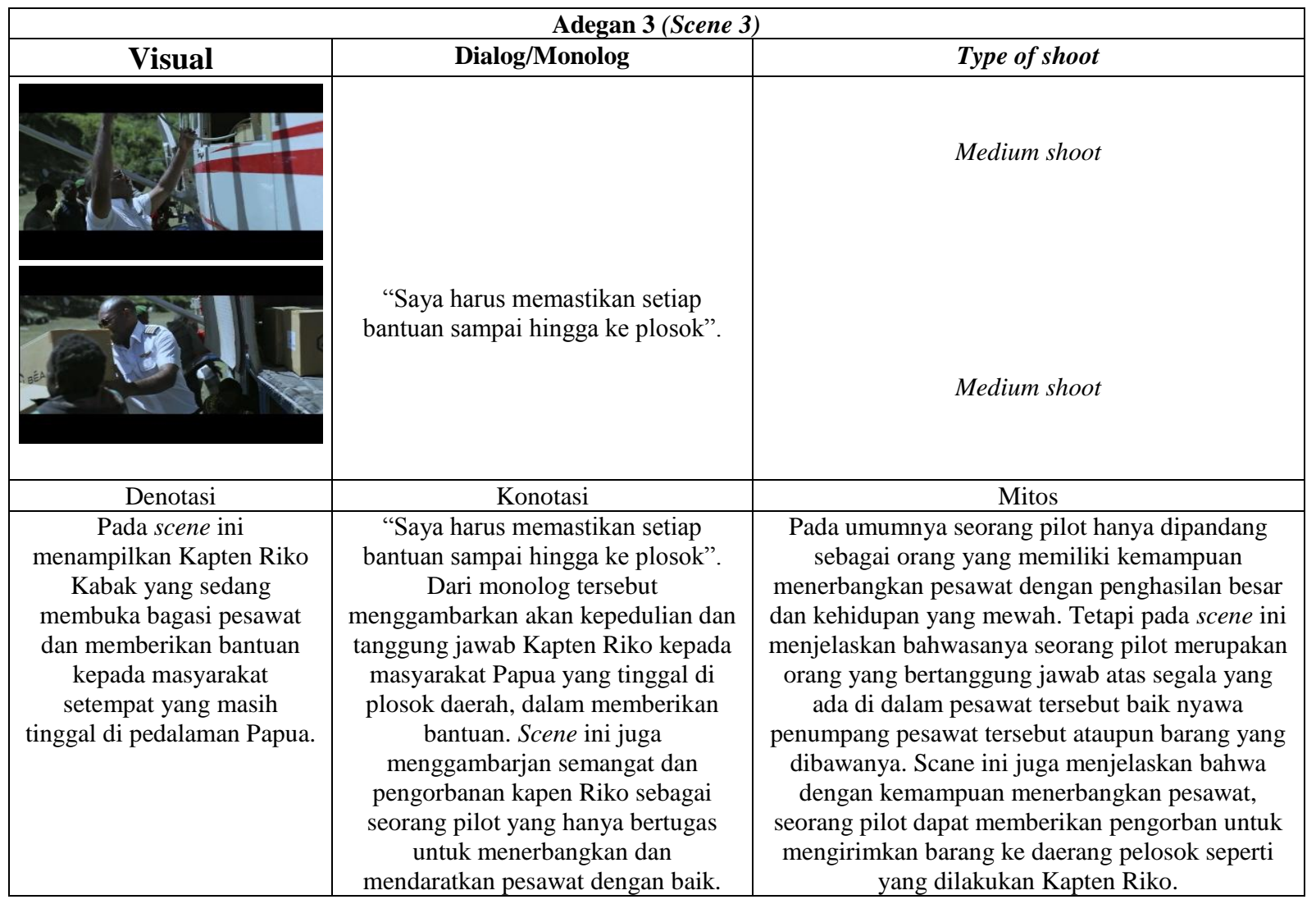




\section{Gambar 3 : Screenshot Sumber Iklan Telkomsel "Menjadi yang Terbaik" versi Pilot Papua, Scene 3 \\ Sumber : Olahan Peneliti}

Pada scene ini, terdapat monolog "saya harus memastikan semua bantuan sampai hingga ke plosok". Monolog ini mencerminkan akan kepedulian yang dimiliki oleh Kapten Riko untuk memastikan setiap bantuan yang ia bawa sampai hingga ke pelosok.Kepedulian Kapten Riko bisa disebabkan oleh tanggung jawab yang dimilikinya sebagai anak asli Papua yang harus memberikan bantuan kepada Papua. Kepedulian dan Tanggung jawab ini menggambarkan akan kepedulian dan tanggung jawab Telkomsel sebagai salah satu anak perusahan dari PT. Telkom Indonesia yang dikelolah oleh BUMN (Badan Usaha Milik Negara) untuk membantu warga yang tinggal di daerah pedalaman khususnya Papua yang masih kesulitan untuk mendapatkan jaringan internet.

Dari kepedulian dan tanggung jawab yang besar, maka timbul kesungguhan dan semangat Kapten Riko untuk selalu membantu masyarakat Papua yang membutuhkan bantuan. Begitu juga dengan Telkomsel yang harus selalu semangat dalam memberikan pelayanan dan inovasi-inovasi terbaik kepada masyarakat Indonesia.

Sebagai seorang pilot, Kapten Riko memberikan pengorbanan yang besar melebihi kapasitasnya yang seharusnya hanya bertugas memastikan pesawat mendarat dengan baik di tempat tujuan, tetapi scene ini juga menggambarkan akan pengorbanan Kapten Riko yang ikut serta menurunkan bantuan yang dibawanya. Kedua visual pada scene ini diambil dengan cara medium shoot. Hal ini untuk memperlihatkan kepedulian, tanggung jawab, semangat dan pengorbanan Kapten Riko sebagai seorang pilot yang berasal dari Papua.

\begin{tabular}{|c|c|c|}
\hline \multicolumn{3}{|c|}{ Adegan 4 (Scene 4) } \\
\hline Visual & Dialog/Monolog & Type of shoot \\
\hline & $\begin{array}{c}\text { Dokter: Kapten Riko ada pasien yang } \\
\text { harus diangkut }\end{array}$ & Close up \\
\hline Denotasi & Konotasi & Mitos \\
\hline $\begin{array}{l}\text { Pada scene ini menampilkan } \\
\text { seorang dokter yang sedang } \\
\text { berkomunikasi dengan Kapten } \\
\text { Riko dengan menggunakan } \\
\text { handphone melalui panggilan } \\
\text { video (video call), Kapten } \\
\text { Rikodimintai bantuan oleh rekan } \\
\text { dokternya untuk segera } \\
\text { membantu pasien. }\end{array}$ & $\begin{array}{c}\text { Pada scene ini menggambarkan } \\
\text { kepedulian Kapten Riko untuk selalu } \\
\text { menolong masyarakat Papua yang } \\
\text { membutuhkan bantuan, termasuk ketika } \\
\text { seorang dokter membutuhkan } \\
\text { bantuannya untuk mengantarkan pasien } \\
\text { yang kritis. Telkomsel sebagai salah satu } \\
\text { operator seluluer juga sangat membantu } \\
\text { Kapten Riko dengan menghubungkan } \\
\text { Kapten Riko dengan rekan dokternya. } \\
\text { Komunikasi tersebut bisa dilakukan } \\
\text { karena adanya jaringan internet } \\
\text { Telkomsel yang begitu luas. }\end{array}$ & $\begin{array}{c}\text { Kebanyakan orang enggan menolong } \\
\text { masyarakat yang ada di daerah } \\
\text { terpencil karena jaringan internet } \\
\text { susah untuk didapatkan sehingga } \\
\text { komunikasi jarak jauh akan sangat } \\
\text { susah. Tetapi dengan luasnya jaringan } \\
\text { internet yang diberikan oleh } \\
\text { Telkomsel maka komunikasi jarak } \\
\text { jauh akan mudah untuk dilakuakan. } \\
\text { Hal tersebut digambarkan pada scene } \\
\text { ini yang mana Kapten Riko bisa } \\
\text { berkomunikasi jarak jauh dengan } \\
\text { dokter dengan bantuan Telkomsel. }\end{array}$ \\
\hline
\end{tabular}

Gambar 4 : Screenshot Sumber Iklan Telkomsel "Menjadi yang Terbaik" versi Pilot Papua, Scene 4

Sumber : Olahan Peneliti 
Dengan niat dan tekat yang kuat untuk menolong masyarakat Papua, maka Kapten Riko melakukan banyak cara untuk membantu masyarakat Papua, salah satunya adalah dengan membantu rekan dokternya yang membutuhkan bantuan untuk membawa pasiennya, dokter tersebut meminta bantuan dengan cara melakukan panggilan video (video call) dengan Kapten Riko.

Visual pada scene ini menunjukkan panggilan video yang dilakukan antara Kapten Riko dan rekan dokternya. Visual ini mencerminkan akan kepedulian dan bentuk bantuan yang diberikan Telkomsel kepada
Pada scene ini terdapat dialog yang dilakukan oleh dokter, "Kapten Riko ada pasien yang harus diangkut". Dialog ini menjadi tanda akan kepedulian dokter terhadap masyarakat Papua. Dokter tersebut menghubungi Kapten Riko karena Kapten Riko juga memiliki kepedulian yang sama terhadapa masyarakat Papua.

masyarakat Papua dengan jaringan internet 4GLTE yang luas sehingga Kapten Riko berkomunikasi dengan rekan dokternya. Teknik pengambilan gambar pada scene ini diambil dengan cara close up.

\begin{tabular}{|l|c|c|}
\hline \multicolumn{1}{|c|}{ Adegan 5 (Scene 5) } & Type of shoot \\
\hline Dialog/Monolog & Medium shoot \\
\hline Kisual & Karena itu saya harus & Medium shoot \\
\hline & selalu terhubung & Medium shoot \\
\hline & & \\
\hline & & \\
\hline
\end{tabular}




\begin{tabular}{|c|c|c|}
\hline Denotasi & Konotasi & Mitos \\
\hline Pada scene ini & Pada scene ini menggambarkan kesigapan Kapten & Tinggal di daerah plosok sangatlah \\
menampilkan Kapten Riko & Rikodengan menjemput dokter untuk menolong \\
yang sedang membuka & warga yang membutuhkan bantuan. Kesigapan yang & terutama bantuan medis. Tetapi \\
pintu pesawat dan & ditunjukkan dalam scene ini juga mewakili & pada scene ini menjelaskan \\
membantu dokter keluar & perjuangan dan kesungguhan Kapten Riko. Ekspresi & bahwasanya masih ada dokter dan \\
dari pesawat tersebut. & wajah Kapten Riko dan dokter pada scene ini & para relawan lain yang siap \\
Kapten Riko dan dokter & menampakkan kepedulian dan kekhawatiran akan & berjuang untuk membantu mereka \\
kemudian bergegas untuk & keadaan anak yang sedang membutuhkan & yang tinggal di daerah plosok. Hal \\
menolong seorang anak & pertolongan karena sakit. Sosok dokter yang sedang & ini diperjelas dengan sosok Kapten \\
kecil. Anak kecil tersebut & memeriksa anak yang tinggal di plosok Papua juga & Riko dan dokter yang siap untuk \\
kemudian diperiksa dan & mewakili tanda akan perhatian Kapten Riko dan & membantu masyarakat yang tinggal \\
dibawah oleh dokter, & dokter terhadap masyarakat Papua. & di daerah plosok. \\
Kapten Riko dan ibunya. & & \\
\hline
\end{tabular}

Gambar 5 : Screenshot Sumber Iklan Telkomsel "Menjadi yang Terbaik" versi Pilot Papua, Scene 5

Sumber : Olahan Peneliti

Pada visual pertama dan kedua, diambil dengan cara medium shoot. Cara ini digunakan untuk menggambarkan akan kesungguhan dan perjuangan Kapten Riko yang diperlihatkan dengan menjemput rekan dokternya untuk memberikan pertolongan kepada masyarakat Papua yang membutuhkan pertolongan. Scene ini mencerminkan semangat Telkomsel untuk selalu memberikan inovasi-inovasi terbaru yang dapat menolong masyarakat Papua.

Semangat Kapten Riko bisa disebabkan oleh kepeduliannya terhadap masyarakat Papua yang juga menjadi tanah kelahirannya. Kepedulian Kapten Riko terlihat dari ekspresi Kapten Riko dan rekan dokternya ketika berlari untuk memberikan pertolongan yang diambil dengan cara medium shoot. Pada visual yang diambil dengan cara medium close up ketika dokter memeriksa anak kecil, juga menamdakan akan kepedulian dokter dan Kapten Riko kepada anak kecil tersebut. Pada scene ini juga terdapat monolog "karena itu saya harus selalu terhubung dengan rekan" yang menjadi tanda akan kesigapan Kapten untuk memberikan pertolongan kepada masyarakat Papua sehingga Kapten Riko harus selalu terhubung dengan rekan untuk memberikan bantuan dengan memilih jaringan internet yang tepat. Kepedulian ini juga tercermin pada usaha Telkomsel untuk menyediakan jaringan internet 4G LTE yang bisa dijangkau oleh siapa pun dan dimana pun berada, bahkan di daerah terpencil sekalipun.

Kesigapan juga ditunjukkan oleh Kapten Riko pada scene ini, yaitu ketika Kapten Riko dan rekan dokternya berlari untuk memberikan pertolongan kepada seorang anak kecil yang sedang sakit. Pada scene ini Telkomsel ingin menjelaskan bahwasanya bantuan yang diberikan kepada masyarakat yang tinggal di daerah terpencil harus dilakukan dengan sigap khususnya bagi masyarakat yang tinggal di tanah Papua dengan segera memperluas jaringan internet Telkomsel, maka Telkomsel mencerminkan dirinya sebagai penyedia jaringan internet yang selalu sigap meleyani kebutuhan konsumen. 


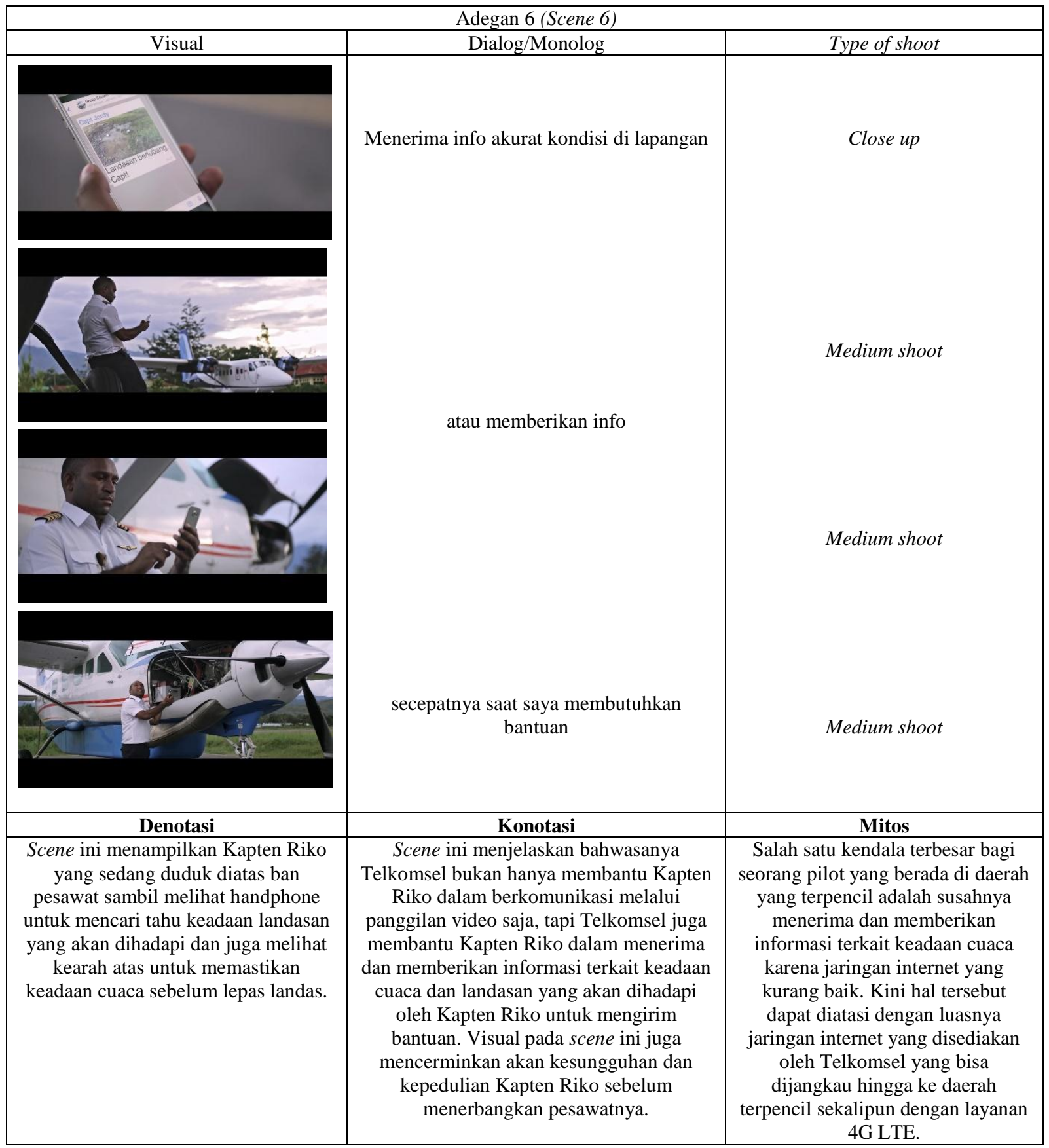

\section{Gambar 6 : Screenshot Sumber Iklan Telkomsel "Menjadi yang Terbaik" versi Pilot Papua, Scene 6}

Sumber : Olahan Peneliti

Visual pertama pada scene ini diambil dengan teknik pengambilan gambar close up. Sedangkan teknik pengambilan gambar yang lain diambil dengan cara medium shoot. Pada scene ini juga terdapat monolog, "menerima info akurat kondisi di lapangan atau memberikan info secepatnya saat saya membutuhkan bantuan". Teknik pengambilan gambar medium shoot dan monolog ini menjadi tanda akan kepedulian Kapten Riko untuk menerima dan memberikan informasi kondisi cuaca dan keadaaan landasan dengan jaringan internet 4G LTE kepada sesama rekan. Sedangkan teknik pengambilan gambar close up, digunakan untuk memperjelas keadaan landasan yang akan dihadapi oleh Kapten Riko. Dengan terbantunya pekerjaan Kapten Riko karena luasnya jaringan internet 
Telkomsel yang bisa dijangkau hingga ke daerah terpencil yang ada di Papua. Kapten Riko bisa menerima dan memberikan informasi terkait keadaan cuaca dan landasan yang akan dihadapi oleh Kapten Riko untuk mengirim bantuan.Telkomsel menggambarkan kepeduliannya kepada masyarakat Papua melalui scene ini. Dengan menyediakan jaringan internet $4 \mathrm{G}$ LTE yang dapat dijangkau hingga ke daerah terpencil sekalipun.

Penggunaan teknik pengambilan gambar medium shoot pada scene ini juga untuk menampilkan wajah Kapten Riko yang begitu serius dalam mengamati informasi yang diterima dari rekannya dan mengamati keadaan cuaca yang akan ia hadapi sebelum lepas landas. Ekspresi wajah ini mencerminkan akan keseriusan dan kesungguhan Kapten Riko dalam menjalankan tugasnya sebagai pilot. Begitu juga keseriusan dan kesungguhan Telkomsel dalam memberikan pelayanan terbaik kepada masyarakat Papua atau kepada para pengguna Telkomsel dimana pun mereka berada. Karena Telkomsel selalu ingin memberikan yang terbaik dan menjadi yang terbaik diantara para kompetitor lainnya.

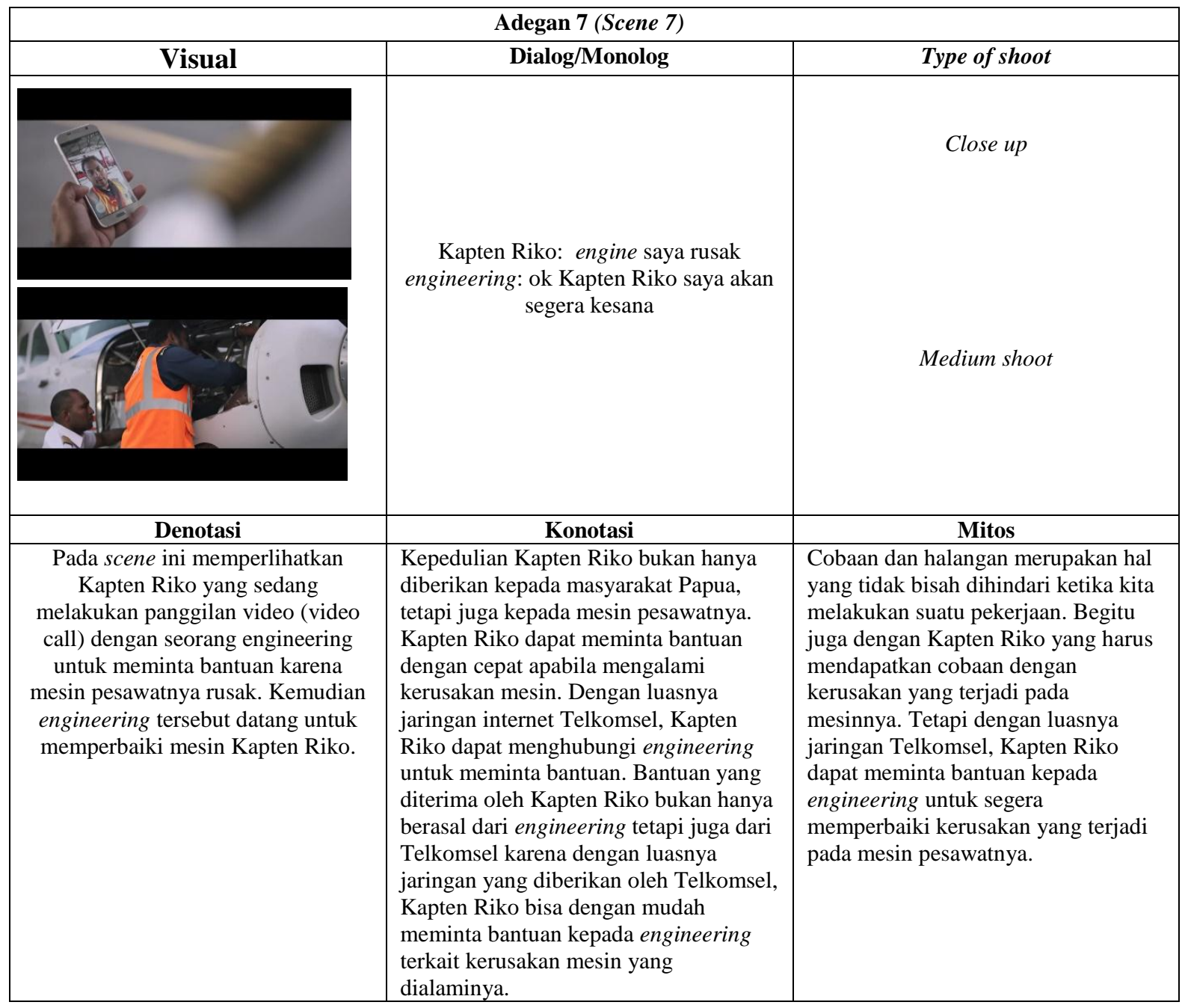

\section{Gambar 7 : Screenshot Sumber Iklan Telkomsel "Menjadi yang Terbaik" versi Pilot Papua, Scene 7}

Sumber : Olahan Peneliti 
Untuk menjadi yang terbaik pasti terdapat hambatan didalamnya. Pada scene ini, hambatan yang harus dihadapi oleh Kapten Riko adalah kerusakan mesin. Dengan luasnya jaringan internet 4G LTE Telkomsel, Kapten Riko dengan mudah dapat berkomunikasi dengan engineering melalui panggilan video (video call) sebagaimana yang terlihat pada visual dan dialok yang terdengar pada scene ini. Kapten Riko: "engine saya rusak". Engineering: "ok Kapten Riko saya akan Visual yang diambil dengan teknik pengambilan gambar medium shoot dan dialog pada scene ini juga merepresentasikan akan kesigapan engineering dalam memberikan pertolongan yaitu dengan memperbaiki mesin pesawat Kapten Riko. Hal ini merepresentasikan akan kesigapan Telkomsel dalam memberikan pelayanan yang terbaik kepada para pengguna Telkomsel, khusunya yang berada di daerah pedalaman seperti Papua. Pada visual kedua dari scene ini, juga segera kesana". Dari dialog ini, mencerminkan akan kepedulian engineering terhadap masalah atau hambatan yang sedang dihadapi oleh Kapten Riko. Pada scene ini merepresentasikan bahwasanya Telkomsel juga turut membantu Kapten Riko dan masyarakat Papua dalam menyelesaikan hambatan yang dihadapai. Pengambilan gambar gilakukan dengan cara close up agar terlihat jelas kualitas gambar panggilan video yang baik.

menggambarkan akan kesungguhan Kapten Riko dan engineering dalam memperbaiki mesin pesawat.

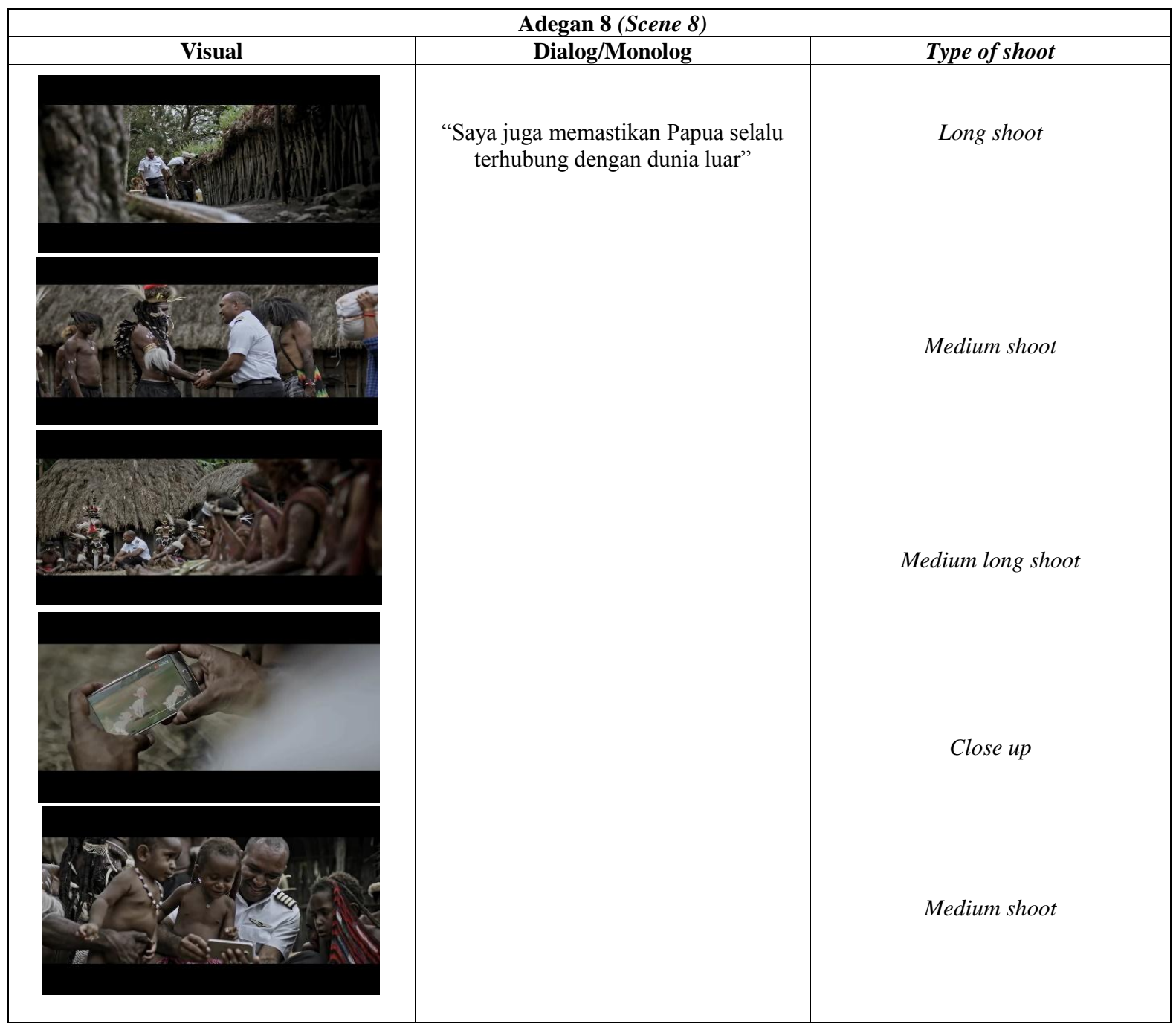




\begin{tabular}{|c|c|c|}
\hline Denotasi & Konotasi & Mitos \\
\hline Pada scene ini menampilkan & Pada scene ini menggambarkan akan & Kebanyakan masyarakat \\
Kapten Riko yang datang di suatu & kesungguhan dan kepedulian Kapten Riko & berpendapat bahwa orang yang \\
daerah terpencil di pulau Papua & terhadap masyarakat Papua dengan & telah mendapatkan pekerjaan yang \\
dengan membawa bantuan berupa & membawakan bantuan secara langsung & mapan apalagi sebagai seorang \\
bahan pokok, kemudian bertemu & kepada masyarakat yang tinggal di daerah & pilot enggan untuk mengunjungi \\
dengan kepala suku daerah & pedalaman Papua. Kesungguhan dan & daerah-daerah pedalaman. \\
tersebut dan berjabat tangan. & kepedulian Kapten Riko di dorong oleh & Kalaupun mengunjungi tentunya \\
Kapten Riko pun duduk bersama & keikhlasan yang besar sehingga Kapten & memiliki tujuan tertentu seperti \\
warga suku tersebut dan bermain & Riko juga mau berkorban untuk & kampanya ataupun yang lainnya. \\
dengan anak-anak kecil dari suku & membawakan bantuan sebagai bentuk dari & Tetapi pada scene ini, Kapten Riko \\
tersebut dengan memperlihatkan & dedikasinya kepada tanah kelahirannya & menepis pandangan tersebut karena \\
video yang berkonten hiburan dari & Papua sebagai seorang pilot. Bukan hanya & pada scene Kapten Riko datang \\
youtube dengan menggunakan & memberikan bantuan, tetapi Kapten Riko & dengan ikhlas untuk membawakan \\
handphone miliknya. Anak-anak & juga menghibur anak-anak Papua dengan & bantuan sebagai bentuk dari \\
suku tersebut pun terlihat senang & mempertontonkan hiburan melalui youtube & kepeduliannya kepada masyarakat \\
dan menonton video tersebut & layaknya anak-anak yang tinggal di daerah & Papua dan dedikasinya kepada \\
dengan seksama. & perkotaan & tanah kelahirannya Papua. \\
\hline
\end{tabular}

Gambar 8 : Screenshot Sumber Iklan Telkomsel "Menjadi yang Terbaik" versi Pilot Papua, Scene 8

Sumber : Olahan Peneliti

Pada scene ini terdapat monolog "saya juga memastikan Papua terhubung dengan dunia luar". Monolog ini menjadi tanda akan kesungguhan Kapten Riko untuk menolong masayarakat Papua. Kapten Riko ingin agar masyarakat Papua dapat menikmati perkembangan zaman yang semakin pesat apalagi di era modern seperti sekarang ini, khusunya perkembangan pada bidang teknologi. Visual pertama, kedua, dan ketiga pada scene ini juga menjadi tanda akan kepedulian Kapten Riko untuk memberikan bantuan secara langsung kepada masyarakat Papua yang berada di daerah pedalaman. Karena sebagai seorang pilot, Kapten Riko tidak memiliki kewajiban untuk mengantarkan bantuan secara langsung hingga sampai kepada masyarakat. Kesungguhan dan kepedulian Kapten Riko kepada masyarakat Papua dalam memberikan bantuan tentunya didasari oleh keikhlasan yang tinggi sehingga Kapten Riko selalu semangat dalam memberikan bantuan kepada masyarakat Papua. Semua yang dilakukan oleh Kapten Riko kepada masyarakat Papua adalah bentuk dari pengabdian dan dedikasinya kepada tanah kelahirannya yaitu Papua.

Kedatangan Kapten Riko disambut dengan hangat oleh kepala suku dan warganya. Hal ini terlihat pada scene kedua dan ketiga yang diambil dengan teknik medium shoot dan medium long shoot. Teknik ini digunakan untuk memperlihatkan keadaan ketika Kapten
Riko berjabat tangan dan duduk Bersama dengan warga suku tersebut. Kedatangan Kapten Riko secara langsung kepada suku tersebut juga membangun keoptimisan dan semangat dalam diri warga tersebut tentunya disebabkan karena tidak banyak orang yang mau datang untuk mengunjungi dan melihat secara langsung keadaan warga suku tersebut yang masih sangat membutuhkan bantuan.

Visual keempat dan kelima pada scene ini diambil dengan teknik pengambilan gambar close up dan medium shoot, yaitu ketika Kapten Riko memberikan hiburan kepada anak-anak Papua dengan mempertontonkan hiburan melalui youtube layaknya anak-anak yang tinggal di daerah perkotaan dan anak-anak tersebut memperlihatkan ekspresi wajah senang. Kedua teknik pengambilan gambar diatas digunakan untuk memperlihatkan kualitas gambar yang baik yang disebabkan oleh jaringan internet yang baik pula dan ekspresi wajah senang. Ekspresi wajah tersebut membangun semangat anak-anak Papua yang tinggal di daerah pedalaman. Kesenangan anak-anak papua tersebut juga menjadi tanda akan kepedulian dan kesungguhan Telkomsel dalam memberikan inovasi dan pelayanan terbaik kepada Papua dengan cara memperluas jaringan internet 4G LTE sehingga masyarakat Papua dapat terhubung dengan dunia luar. 


\begin{tabular}{|c|c|c|}
\hline \\
\hline \multicolumn{3}{|c|}{$\begin{array}{c}\text { Adegan } 9 \text { (Scene 9) } \\
\text { Dialog/Monolog }\end{array}$} \\
\hline & Selama Papua membutuhkan & Close up \\
\hline & & Close up \\
\hline & & Close up \\
\hline Denotasi & Konotasi & Mitos \\
\hline $\begin{array}{l}\text { Pada scene ini menampilkan wajah dan } \\
\text { pakaian asli dari salah suku yang berasal } \\
\text { dari tanah Papua dengan monolog } \\
\text { "selama Papua membutuhkan" }\end{array}$ & $\begin{array}{l}\text { Gambar pada scene ini mewakili } \\
\text { tanda bahwasanya warga Papua yang } \\
\text { tinggal di pedalaman sangat berharap } \\
\text { untuk mendapatkan bantuan dan } \\
\text { perhatian. Dalam scene ini juga } \\
\text { terdengar Monolog "selama Papua } \\
\text { membutuhkan", Monolog ini } \\
\text { mewakili akan kepedulian anak asli } \\
\text { Papua yang siap mengerahkan } \\
\text { kemampuannya untuk tanah } \\
\text { kelahirannya sebagai bentuk dari } \\
\text { tanggung jawab dan pengabdian } \\
\text { dirinya, }\end{array}$ & $\begin{array}{l}\text { Pada umumnya, seorang putra } \\
\text { daerah yang telah mendapatkan } \\
\text { suatu pekerjaan yang mapan } \\
\text { enggan untuk kembali kedaerahnya } \\
\text { dan menolong masyarakat yang } \\
\text { tinggal di daerahnya. Tetapi scene } \\
\text { ini mematahkan pandangan diatas, } \\
\text { karena Kapten Riko meskipun } \\
\text { telah menjadi seorang pilot, dia } \\
\text { tetap mencurahkan kepeduliannya } \\
\text { kepada Papua yang menjadi daerah } \\
\text { kelahirannya. }\end{array}$ \\
\hline
\end{tabular}

\section{Gambar 9 : Screenshot Sumber Iklan Telkomsel "Menjadi yang Terbaik" versi Pilot Papua, Scene 9}

Sumber : Olahan Peneliti

Pada scene ini terdapat monolog "selama Papua membutuhkan", Monolog ini menjelaskan akan kepedulian seorang anak Papua asli yang siap mengerahkan kemampuannya untuk Papua. Kepedulian tersebut muncul dari tanggung jawab yang dimilikinya sebagai anak Papua asli yang harus mengabdikan diri kepada daerahnya.
Pada scene ini Telkomsel menggambarkan kepedulian untuk mengarahkan kemampuan terbaiknya dan inovasi-inovasi terbaru untuk memberikan pelayanan terbaik kepada masyarakat Papua sebagai bentuk dari tanggung jawab Telkomsel dan pengabdian diri kepada masyarakat Indonesia. 
Pengambilan gambar pada scene ini diambil dengan cara close up, penggunaan cara ini untuk menampilkan kebudayaan asli masyarakat Papua dengan memperlihat pakaian adat orang Papua dan ekspresi wajak masyarakat asli Papua yang penuh dengan harapan akan bantuan. Ekspresi tersebut menjadi gambaran bahwasanya Telkomsel memberikan harapan baru bagi masyarakat yang tinggal di daerah Papua. Karena dengan luasnya jaringan internet Telkomsel, masyarakat Papua dengan mudah dapat berkomunikasi, memberikan dan mendapatkan informasi dengan cepat

\begin{tabular}{|c|c|c|}
\hline \multicolumn{3}{|c|}{ Adegan 10 (Scene10) } \\
\hline Visual & Dialog/Monolog & Type of shoot \\
\hline & & Medium shoot \\
\hline & & Long shoot \\
\hline 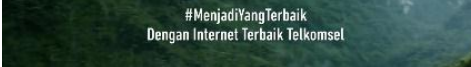 & & Long shoot \\
\hline Denotasi & $\begin{array}{c}\text { Konotasi } \\
\end{array}$ & Mitos \\
\hline $\begin{array}{l}\text { Pada scene ini menampilkan Kapten } \\
\text { Riko yang sedang bersiap untuk } \\
\text { menerbangkan pesawatnya diatas } \\
\text { landasan yang hanya tanah lapang } \\
\text { yang becek. Dan setelah pesawat } \\
\text { tersebut terbang terdapat tulisan } \\
\text { "Menjadi yang" terbaik Dengan } \\
\text { Internet Terbaik Telkomsel. }\end{array}$ & $\begin{array}{l}\text { Scene ini menampilkan sosok Kapten } \\
\text { Riko dengan monolog "saya akan tetap } \\
\text { berada di udara", monolog ini } \\
\text { menggambarkan akan } \\
\text { kesungguhanKapten Rikountuk terus } \\
\text { mengabdikan diri terhadap pekerjaannya } \\
\text { sebagai seorang pilot } \\
\text { dan terus menerbangkan pesawatnya } \\
\text { apapun rintangannya, bahkan diatas } \\
\text { landasan yang beresiko sekalipun sebagai } \\
\text { bentuk dari perjuangannya kepada } \\
\text { masyarakat Papua. Melalui scene ini, } \\
\text { Telkomsel juga ingin merepresentasikan } \\
\text { operator seluler mereka dengan sosok } \\
\text { Kapten Riko Kabak dan tulisan menjadi } \\
\text { yang terbaik dengan internet terbaik } \\
\text { Telkomsel. Tulisan tersebut menjelaskan } \\
\text { bahwa Telkomsel ingin menjadi yang } \\
\text { terbaik dengan menyediakan jaringan } \\
\text { internet terluas yang bisa diakses hingga } \\
\text { ke daerah pedalaman Papua. }\end{array}$ & $\begin{array}{l}\text { Secara umum menjadi yang } \\
\text { terbaik biasanya disimbolkan } \\
\text { dengan kemewahan dan } \\
\text { ketenaran, tetapi pada scene ini } \\
\text { menunjukkan bahwa menjadi } \\
\text { yang terbaik adalah orang-orang } \\
\text { yang mampu melalui segalah } \\
\text { tantangan yang orang lain tidak } \\
\text { mampu melaluinya. Sebagaimana } \\
\text { yang dicontohkan Kapten Riko } \\
\text { yang selala siap sedia untuk } \\
\text { mengirimkan bantuan hingga ke } \\
\text { plosok Papua dengan menghadap } \\
\text { segala tantangan. Begitu juga } \\
\text { dengan Telkomsel yang memiliki } \\
\text { misi untuk menjadi operator } \\
\text { seluler terbaik dengan jangkauan } \\
\text { internet terluas di Indonesia. }\end{array}$ \\
\hline
\end{tabular}

Gambar 10 : Screenshot Sumber Iklan Telkomsel "Menjadi yang Terbaik" versi Pilot Papua, Scene 10

Sumber : Olahan Peneliti 
Visual pertama pada scene ini diambil dengan teknik medium shoot. Teknik ini digunakan untuk memperlihatkan ekspresi wajah Kapten Riko yang mencerminkan akan kesungguhan Kapten Riko untuk menerbangkan pesawatnya dan menghadapai segala halangan yang akan dihadapinya untuk memberikan yang terbaik kepada Papua dengan keahliannya menerbangkan pesawat. Monolog "saya akan tetap berada di udara" juga menjadi tanda akan kesungguhan Kapten Riko. Kesungguhan Kapten Riko tentunya di dorong oleh kepeduliannya terhadap masyarakat Papua. Kesungguhan Kapten Riko juga menggambarkan akan pengabdaian dirinya kepada Papua. Visual dan monolog pada scene ini juga menggambarkan kesungguhan Telkomsel dalam menghadapi segala halangan dan rintangan yang akan mereka hadapi dalam memberikan pelayanan terbaik kepada masyarakat Indonesia, khususnya masyarakat yang tinggal di Papua. Ini juga bentuk pengabdian diri Telkomsel kepada masyarakat Indonesia.

Visual kedua pada scene ini diambil dengan teknik pengambilan gambar long shoot. Teknik ini digunakan untuk memperlihatkan pesawat yang akan lepas landas diatas landasan yang hanya tanah lapang dan becek dalam. Visual ini mencerminkan akan perjuangan dan keberanian Kapten Riko untuk menghadapi tantangannya sebagai seorang pilot. Landasan yang becek pada scene ini juga mencerminkan akan halangan yang harus dihadapi oleh Telkomsel.

Teknik pengambilan gambar pada visual ketiga dalam scene ini juga diambil dengan teknik long shoot. Teknik ini digunakan untuk memperlihatkan latar daerah Papua yang memang dikelilingi oleh pegunungan dan pesawat merupakan alat transportasi tercepat yang dapat digunakan. Pada visual ini terdapat tulisan atau jargon "Menjadi Yang Terbaik Tengan Dengan Internet Terbaik Telkomsel". Dengan jargon ini, Telkomsel ingin menunjukkan bahwasanya Telkomsel merupakan operator seluler terbaik yang ada di Indonesia dengan jangkauan internet terluas hingga ke daerah pedalaman Papua. Untuk menjadi operator seluler terbaik Telkomsel harus semangat dalam berinovasi dalam memberikan pelayanan terbaik, pengorbanan dan kepedulian terhadap kebutuhan masyarakat yang tinggal di daerah pedalaman, seperti apa yang dilakukan oleh Kapten Riko pada scene ini, yaitu selalu mencurahkan waktu, tenaga dan pikirannya kepada masyarakat Papua yang juga menjadi tanah kelahirannya.

Scene ini merupakan gambaran akan visi Telkomsel sebagai penyedia layanan dan solusi gaya hidup digital mobile kelas dunia yang terpercaya dan misi untuk memberikan layanan dan solusi digital mobile yang melebihi ekspetasi para pengguna, menciptakan nilai lebih bagi para pemegang saham serta mendukung pertumbuhan ekonomi bangsa.

\section{Makna tagline "Menjadi Yang Terbaik"}

Setelah mengurai tanda-tanda pada kedua iklan diatas, peneliti mengintrepetasikan makna tagline "Menjadi yang Terbaik" melalui analisis isi pesan, pada iklan Telkomsel versi pilot Papua Kapten Riko Kabak sebagai berikut:

(1) Kesungguhan. Jika semangat adalah bahan bakar, maka sungguh-sungguh bagaikan pelumas. Suatu hal yang menjadi syarat mutlak untuk sempurnanya kinerja. Semangat dan sungguh-sungguh bagaikan sahabat karib yang tidak bisa dipisahkan. Yang satu sangat membutuhkan yang lain. Jika semangat merupakan syarat mutlak untuk dapat bergerak aktifnya diri maka kesungguhan adalah sarat mutlak untuk sempurna dan berhasilnya gerakan itu. Tanpa adanya kesungguhan mustahil suatu tujuan dapat tercapai. Bahkan akan terasa teramat sangat berat untuk dilakukan.

Dalam kamus Besar Bahasa Indonesia (KBBI), kesungguhan merupakan perbuatan sungguh-sungguh. Sedangkan sungguhsungguh memiliki artitidak main-main; dengan segenap hati; dengan tekun; benar-benar. Jika dilihat dari arti sungguh-sungguh, maka dapat disimpulkan bahwa bersungguh-sungguh lebih berat daripada sekedar bersemangat karena kesungguhan menuntut tidak hanya sikap mental tetapi juga sikap fisik yang berarti pengerahan energi fisik. Sungguh-sungguh juga berat karena dia adalah lawan dari mainmain. Yang namanya main-main pastilah jauh dari kesan berat, capek, dan sebagainya maka dapat dibayangkan lawan dari main-main. 
Kesungguhan menuntut kesabaran dalam waktu yang tidak sebentar.

Semangat dan kesungguhan tentunya di dorong oleh niat dan tekad yang kuat. Dalam KBBI online niat adalah maksud atau tujuan suatu perbuatan atau bisa juga diartikan kehendak. Sedangkan tekad adalah kemauan atau kehendak yang pasti atau bisa juga diartikan sebagai kebulatan hati. Jadi niat merupakan kehendak atau kemauan untuk melakukan sesuatu, tetapi tekad lebih cenderung kepada ketetapan hati atau komitmen untuk melakukan sesuatu.

Pada iklan Telkomsel versi Kapten Riko Kabak, kesungguhan Kapten Riko terlihat pada visual scene pertama ketika Kapten Riko harus menghadapi angin dan cuaca yang ekstrim, dan monoloh "adalah hal yang harus saya hadapi". Ekspresi wajahnya pada scene kedua, yang menandakan akan kesungguhannya untuk mengabdikan diri kepada Papua. Pada scene kelima, Kapten Riko juga menunjukkan kesungguhan dan semangatnya dalam memberikan pertolongan kepada masyarakat Papua. Pada scene keenam, kesungguhan Kapten Riko juga terlihat dari ekspresi wajahnya ketika Kapten Riko menerima informasi dari rekannya dan mengamati keadaan cuaca yang akan dihadapi sebelum lepas landas. Kesungguhan juga terlihat pada scene ketujuh ketika Kapten Riko dan enginnering bersungguh-sungguh dalam memperbaiki mesin pesawat Kapten Riko. Pada scene kesepuluh, monolog "saya akan tetap berada di udara" dan ekspresi wajah Kapten Riko juga menjadi tanda akan kesungguhan Kapten Riko dalam memberikan pertolongan kepada Papua.

Begitu juga Telkomsel, kesungguhan, niat dan tekad yang kuat diperlihatkan oleh terkomsel melalui visi dan misinya yang mengarah kepada tema menjadi yang terbaik. Dengan visi Telkomsel sebagai penyedia layanan dan solusi gaya hidup digital mobile kelas dunia yang terpercaya dan misi untuk memberikan layanan dan solusi digital mobile yang melebihi ekspektasi para pengguna, menciptakan nilai lebih bagi para pemegang saham serta mendukung pertumbuhan ekonomi bangsa, maka Telkomsel akan melakukan hal-hal yang mengarah kepada pencapaian visi dan misi.
(2) Kepedulian. Dalam KBBI (Kamus Besar Bahasa Indonesia) kepedulian berasal dari kata peduli, yang berarti mengindahkan, memperhatikan atau menghiraukan. Sedangkan kepedulian sendiri memiliki makna, sikap mengindahkan atau memprihatinkan sesuatu yang terjadi dalam masyarakat. Kepedulian bisa juga diartikan sebagai emosi manusia yang muncul akibat penderitaan orang lain. Lebih kuat daripada empati, perasaan ini biasanya memunculkan usaha mengurangi penderitaan orang lain.

Pada iklan Telkomsel versi pilot Papua Kapten Riko kabak memiliki banyak sekali tanda yang menandakan akan kepedulian Kapten Riko kepada Papua. Hampir setiap scene memiliki tanda akan kepedulian Kapten Riko. Kepedulian Kapten Riko terlihat pada scene ketiga higga scene kesembilan. Pada scene ketika kepedulian Kapten Riko terlihat pada Monolog "saya harus memastikan semua bantuan sampai hingga ke plosok". Monolog ini mencerminkan akan kepedulian yang dimiliki oleh Kapten Riko untuk memastikan setiap bantuan yang ia bawah sampai hingga ke pelosok. Untuk scene keempat dan kelima sama-sama menandakan akan kepedulian Kapten Riko dan rekan dokternya kepada masyarakat Papua. Scene keempat terlihat dari dialog dokter Kapten Riko ada pasien yang harus diangkut". Sedangkan scene kelima terlihat dari ekspresi Kapten Riko dan rekan dokternya ketika berlari untuk memberikan pertolongan untuk memberikan pertolongan kepada seorang anak kecil.

Pada scene keenam, kepedulian Kapten Riko terlihat dari monolog "menerima info akurat kondisi di lapangan atau memberikan info secepatnya saat saya membutuhkan bantuan". Monologini menjadi tanda akan kepedulian Kapten Riko untuk menerima atau memberikan informasi kepada sesama rekan. Kepedulian pada scene ketujuh terlihat dari jawaban enginnering"ok Kapten Riko saya akan segera kesana"."saya juga memastikan Papua terhubungun dengan dunia luar". Monolog ini juga menjadi tanda akan kepedulian Kapten Riko kepada masayarakat Papua pada scene kedelapan. Sedangkan pada scene kesembilan, monolog "selama Papua membutuhkan" menjadi tanda akan kepedulian Kapten Riko kepada masyarakat Papua. 
Iklan tersebut seolah ingin merepresentasikan keinginan Telkomsel yang ingin dilihat sebagai provider yang memiliki kepedulian. Melalui usaha memperluas jaringan internet yang bisa diakses hingga ke daerah pedalaman, Telkomsel ingin menunjukkan bahwasa Telkomsel mengerti dan memikirkan kebutuhan masyarakat semua lapisan, bukan hanya kepada masyarakat yang tinggal di daerah perkotaan saja tetapi juga kepada masyarakat yang tinggal di daerah pedalaman.

(3) Perjuangan. Dalam KBBI (Kamus Besar Bahasa Indonesia), perjuangan memiliki arti usaha yang penuh dengan kesukaran dan bahaya. Dalam perjuangan akan banyak sekali halangan dan rintangan yang harus dihadapi. Perjuangan bagaikan jalan yang tak berujung. Meskipun kita telah berhasil menghadapi suatu rintangan, maka akan datang lagi rintanga yang lain, begitu seterusnya. Maka perjuangan tentunya didorong oleh nilai-nilai lain yang dapat memperkuat perjuangan tersebut agar tidak mudah untuk goyah.

Pada iklan Telkomsel versi Kapten Riko, perjuangan Kapten Riko terlihat pada scene pertama, kedua, kelima dan kesepuluh. Pada scene pertama, perjuangan Kapten Riko terlihat ketika Kapten Riko harus menghadapi bahaya berupa angin yang kencang, pegunungan yang tinggi dan cuaca yang ekstrim. Scene kedua, perjuangan Kapten Riko terlihat ketika Kapten Riko harus berusaha untuk mendaratkan pesawatnya diatas tanah yang becek dan beresiko untuk mengalami kecelakaan. Pada scene kelima, perjuangan terlihat ketika Kapten Riko harus menjemput seorang dokter terlebih dahulu untuk menolong warga yang membutuhkan pertolongan medis. Dan pada scene kesepuluh, perjuangan kapen Riko terlihat ketika Kapten Riko harus berusaha untuk menerbangkan pesawatnya diatas tanah yang becek.

Telkomsel sebagai operator telekomunikasi terbaik di Indonesia ingin menunjukkan kepeduliannya dalam berjuang mengikuti perembangan teknologi yang semakin berkembang sehingga dapat memberikan pelayanan terbaik kepada masyarakat Indonesia. Dalam perjuangannya Telkomsel harus menghadapi segala permasalahan yang pastinya akan ada. Dan untuk mengghadapi semua permasalahan tersebut, maka Telkomsel harus memiliki persiapan.

(4) Tanggung Jawab. Pengertian tanggung jawab secara umum adalah kesadaran manusia akan tingkah laku atau perbuatan baik yang disengaja maupun yang tidak di sengaja. Tanggung jawab juga berarti berbuat sebagai perwujudan kesadaran akan kewajiban (www.zonareferensi.com). Tanggung jawab selalu melekat dengan kehidupan manusia, karena setiap manusia pasti dibebani oleh tanggung jawab, baik secara sadar akan akibat baik atau buruk dari perbuatannya atau secara tidak sadar. Oleh sebab itu, tanggung jawab dapat dilihat dari sisi orang yang berbuat dan sisi kepentingan orang lain.

Pada iklan Telkomsel versi Kapten Riko Kabak, tanggung jawab Kapten Riko terlihat pada scene ketiga dan scene kesembilan. Pada scene ketiga, tanggung jawab Kapten Riko terlihat pada monolog "saya harus memastikan semua bantuan sampai hingga ke plosok" yang mencerminkan tanggung jawab Kapten Riko sebagai anak asli Papua. Sedangkan pada scene kesembilan, tanggung jawab Kapten Riko terlihat pada monolog "selama Papua membutuhkan" yang juga menjadi cerminan akan kepedulian seorang anak Papua asli yang siap mengerahkan kemampuannya untuk Papua.

Peluasan jaringan internet 4G LTE yang dlakukan menjadi bentuk dari tanggung jawab Telkomsel sebagai operator seluler yang bertugas untuk memberikan pelayanan terbaik kepada masyarakat Indonesia, khususnya bagi masyarakat Indonesia yang berada di daerah pedalaman karena 4G LTE dapat diakses hingga ke daerah pedalaman.

(5) Keberanian. Dalam KBBI (kamus Besar Bahasa Indonesia), kata berani memiliki makna mempunyai hati yang mantap dan rasa percaya diri yang besar dalam menghadapi bahaya, kesulitan, dan sebagainya. Sedangkan keberanian adalah keadaan berani. Tanpa keberanian kita tidak bisa melalui segala kesulitan dan tantangan dalam hidup. Karena keberanianlah yang membuat kita mampu dan bertahan. Jika dilihat dari makna kata berani, terdapat beberapa scene yang ada pada kedua iklan diatas yang menggambarkan akan keberanian Kapten Riko Kabak.

Pada iklan Telkomsel versi Kapten Riko Kabak, keberanian terlihat pada scene 
pertama, kedua dan kesepuluh. Pada scene pertama, keberanian Kapten Riko terlihat pada monolog "angin kencang, cuaca ekstrim, pegunungan tinggi, adalah hal yang harus saya hadapi". Monolog ini merupakan tanda akan keberanian Kapten Riko dalam menghadapi rintangan. Pada scene yang kedua, keberanian Kapten Riko terlihat ketika Kapten Riko harus mendaratkan pesawatnya diatas tanah yang becek, karena dibutuhkan keberanian untuk mendaratkan pesawat diatas tanah yang becek. Sedangkan pada scene kesepuluh, Keberanian Kapten Riko terlihat ketika Kapten Riko harus menerbangkan pesawatnya dari landasan yang becek.

Scene-scene dalam Iklan Telkomsel versi Riko Kabak menggambarkan keberanian Telkomsel dalam menghadapi segala halangan dan resiko untuk menjadi operator telekomunikasi terbaik di Indonesia. Jika dilihat dari logo Telkomsel, heksagon merah melambangkan seluler, warna merah sendiri bermakna Telkomsel berani dan siap menyongsong masa depan dengan segala perkembangan teknologi telekomunikasi yang berkembang dengan sangat pesat seperti sekarang ini. Pertemuan dua lingkaran berwarna putih di atas heksagon merah melambangkan bentuk huruf ' $t$ ' sebagai huruf awal Telkomsel. Warna putih pada huruf ' $t$ ' tersebut mengandung makna keberanian, keterbukaan, dan transparansi.

(6) Kesigapan. Menurut KBBI (Kamus Besar Bahasa Indonesia), kesigapan memiliki makna bergerak atau bertindak disertai semangat yang tinggi. Jika dilihat dari arti kesigapan, maka semangat dan kesigapan merupakan satu paket yang tidak bisa dipisahkan. Dengan adanya semangat yang tinggi, maka seseorang akan melakukan suatu tindakan dengan sigap.

Dalam iklan Telkomsel versi Kapten Riko Kabak, kesigapan terlihat pada scene kelima dan ketujuh. Kesigapan pada scene kelima terlihat ketika Kapten Riko dan rekan dokternya berlari untuk memberikan pertolongan kepada seorang anak kecil yang sedang sakit. Sedangkan kesigapan pada scene ketujuh terlihat ketika Kapten Riko meminta bantuan kepada rekan engineeringnya. Scene ini menunjukkan akan kesigapan engineering dalam menolong Kapten Riko yang terdengar pada dialog "ok Kapten Riko, saya akan segera kesana" dan juga visual ketika engineering memperbaiki mesin pesawat Kapten Riko pada scene ini. Peningkatan kualitas jaringan internet Telkomsel dengan selalu berinovasi dan memberikan program-program terbaru menjadi gambaran usaha Telkomsel yang melakukan kesigapan dalam mengikuti perkembangan kebutuhan konsumennya.

(7) Pengorbanan. Dalam KBBI (Kamus Besar Bahasa Indonesia), pengorbanan memiliki arti perbuatan mengorbankan. Mengorbankan sendiri memiliki arti menyatakan kebaktian, kesetiaan dan sebagainya. Jika dilihat dari arti pengorbanan diatas, pengorbanan juga merupakan suatu tindakan atas kesadaran yang tulus dan ikhlas atau juga bisa diartikan sebagai kerelaan seseorang akan suatu hal yang biasanya ditunjukan pada seseorang yang mempunyai tujuan atau makna dari tindakannya itu, dalam bentuk pertolongan dan tidak mengharapkan imbalan dari suatu tindakan atau kerelaan, ikhlas semata-mata karna Tuhan. Pengorbanan dilakukan secara ikhlas tanpa pamrih, tanpa ada perjanjian, tanpa ada transaksi, kapan saja diperlukan. Orang-orang yang berkorban biasanya adalah orang-orang yang melakukannya dengan ikhlas semata-mata karna Allah. Orang-orang yang berkorban berfikir bahwa pengorbanannya yang sedikit ataupun banyak akan berguna dan berarti sekali untuk orang yang menerima pengorbanannya itu.

Pada iklan Telkomsel versi Kapten Riko, pengorbanan Kapten Riko terlihat pada visual scene ketiga, yaitu dengan ikut serta menurunkan bantuan yang dibawah olehnya. Padahal sebagai seorang pilot, Kapten Riko hanya memiliki kewajiban untuk mendaratkan pesawatnya dengan baik di tempat tujuan. Pada scene kedelapan juga tergambarkan akan pengorbana Kapten Riko yang terlihat pada visual pertama, kedua, dan ketiga pada scene tersebut, yang menjadi tanda akan pengorbanan Kapten Riko untuk memberikan bantuan secara langsung kepada masyarakat Papua yang berada di daerah pedalaman. Padahal sebagai seorang pilot, Kapten Riko tidak memiliki kewajiban untuk mengantarkan bantuan secara langsung hingga sampai kepada masyarakat. Telkomsel seolah ingin menjelaskan bahwasanya menolong bukanlah suatu hal yang mudah. Dibutuhkan pengorbanan yang besar untuk menghadapi 
segala rintangan untuk menjadi operator seluler terbaik di Indonesia.

(8) Dedikasi atau Pengabdian Diri. Dedikasi adalah sebuah pengorbanan tenaga, pikiran, dan waktu demi keberhasilan suatu usaha yang mempunyai tujuan yang mulia, dedikasi ini bisa juga berarti pengabdian untuk melaksanakan cita-cita yg luhur dan diperlukan adanya sebuah keyakinan yang teguh (www.wikipedia.org). Jika dilihat dari makna dedikasi, maka kesungguhan, kepedulian, keberanian, kesigapan dan pengorbanan merupakan bentuk dari dedikasi atau pengabdian diri Kapten Riko Kabak kepada Papua kepada masyarakat yang tinggal di daerah pedalaman melalui profesinya sebagai pilot. Bukan hanya untuk dirinya sendiri (karir), tetapi menjadi yang terbaik untuk masyarakat yang ada disekitar.

Menurut intrepetasi peneliti, iklan Telkomsel versi pilot Papua Riko Kabak dibuat dengan tujuan ingin menggambarkan dedikasi Telkomsel sebagai anak perusahaan dari Telkom Group yang dikelolah oleh BUMN kepada masyarakat Indonesia, khususnya masyarakat yang tinggal di daerah pedalaman dengan memberikan pelayanan terbaik. Salah satu cara untuk membarikan layanan terbaik adalah dengan memperluas jaringan internet 4G LTE, sehingga masyarakat yang berada di daerah pedalaman dapat mengakses internet dengan mudah, dengan kualitas jaringan yang baik.

Melalui hasil analisa peneliti terkait isi pesan iklan tersebut dapat dimaknai bahwa untuk menjadi yang terbaik, maka harus memiliki kesungguhan di dalam diri. Kesungguhan ini tentunya di dorong oleh niat dan tekad yang kuat untuk melakukan sesuatu. Dalam kehidupan bermasyarakat, kepedulian terhadap sesama dapat menjadi pemicu untuk melakukan suatu usaha yang menimbulkan kemaslahatan untuk masyarakat. Usaha yang dilakukan tersebut merupakan bentuk dari tanggung jawab untuk menciptakan kemaslahatan. Kemaslahatan tersebut, dapat diciptakan dengan keberanian dan rasa percaya diri untuk memulai dan melakukan tindakantindakan yang disertai dengan semangat yang tinggi demi terciptanya kemaslahatan tersebut. Tentunya untuk menciptakan kemaslahatan tidaklah mudah, dibutuhkan pengorbanan. Pengorbanan biasanya dilandasi oleh kesadaran yang tulus dan ikhlas. Maka dari itu demi terciptanya kemaslahatan, maka dibutuhkan dedikasi yang terbentuk dari kesungguhan, kepedulian, usaha, tanggung jawab, keberanian, percaya diri, semangat yang tinggi dan pengorbanan. Makna tersebut seolah sengaja ingin merepresentasikan Visi Telkom Group dan Telkomsel keduanya samasama mengarah kepada tagline "menjadi yang terbaik". Telkom Group memiliki visi Be the King of Digital in the Region, Kata The King pada visi Telkom Group menandakan bahwasanya Telkom Group mempunya ambisi untuk menjadi yang terbaik. Sedangkan Telkomsel memiliki visi "menjadi penyedia layanan dan solusi gaya hidup digital mobile kelas dunia yang terpercaya". Jika dilihat dari makna kata-kata pada visi Telkomsel, Telkomsel juga memiliki ambisi untuk menjadi yang terbaik. Hal ini sesuai dengan tagline yang digunakan pada iklan Telkomsel, yaitu "Mmenjadi Yang Terbaik".

\section{SIMPULAN}

Dari hasil analisa isi pesan iklan Telkomsel versi Pilot Papua Kapten Riko Kabak dapat diambil kesimpulan bahwa makna tagline "Menjadi Yang Terbaik" adalah sebuah kesatuan usaha seseorang dalam melaksanakan sebuah tugas yang didasari kesungguhan, kepedulian, perjuangan, tanggung jawab, keberanian, kesigapan, pengorbanan dan dedikasi atau pengabdian diri. Untuk menjadi yang terbaik, maka harus memiliki kesungguhan di dalam diri. Kesungguhan ini tentunya di dorong oleh niat dan tekad yang kuat untuk melakukan sesuatu. Selain kesungguhan harus ada sesuatu yang tumbuh lebih kuat dari rasa empati, yaitu kepedulian. Kepedulian inilah yang menjadi pemicu timbulnya suatu usaha yang lebih atau perjuangan. Perjuangan yang dilakukan tersebut pastinya berlandaskan atas kesadaran akan kewajiban bukan atas tekanan atau paksaan dari pihak lain,atau biasa disebut dengan tanggung jawab.Untuk menjadi yang terbaik pasti akan ada halangan dan rintangan yang selalu datang silih berganti, maka dari itu harus ada keberanian untuk menghadapi segala halangan dan rintangan tersebut, baik keberanian dalam mengambil tindakan, keputusan, resiko dan lain-lain sebagainya. 
Setelah keberanian, maka setiap tindakan yang dilakukan haruslah dilakukan dengan sigap dan disertai dengan semangat yang tinggi, bahkan harus siap untuk mengorbankan tenaga, pikiran dan waktu demi tercapainya suatu tujuan yang diinginkan. Inilah yang disebut dengan pengorbanan. Kesungguhan, kepedulian, perjuangan, tanggung jawab, keberanian, kesigapan dan pengorbanan merupakan nilai-nilai yang menggiring seseorang untuk berdedikasi.

\section{DAFTAR PUSTAKA}

Akbar, Taufik. 2014.Cause Category dan Product Type dan Respon Konsumen. Jurnal Lentera Bisnis. Vol 3, No. 1, 1

Andini, Lily, Puspita.2016. Pengaruh Persepsi Celebrity Endorse dan Tagline Iklan Terhadap Brand Awarness Konsumen Pada Produk Wardah Dikalangan Mahasiswi UIN Malik Malang. Skripsi tidak diterbitkan. Malang: Fakultas Psikologi Universitas Islam Maulana Malik Ibrahim.

Chaidir, M, Prakoso, Cathas, Teguh dan Boer, Kheyene, Molekandella. 2018. Pengaruh Tagline Iklan Yamaha "Semakin Di Depan" Terhadap Kesadaran Merek Pada Masyarakat Kecamatan Samarinda Ulu DI Kota Samarinda. eJurnal Ilmu Komunikasi, 6(1):391-402

Djama'an, Satori dan Aan, komariah, 2013. Metodologi Penelitian Kualitatif. Cetakan Kelima, Bandung: Alvabeta

Halim, Seanny, Kurniawati, Swandi I Wayan, Raditya Alvin.Perancangan Corporate Identity Espacion Interior Design Makassar, Surabaya: Desain Komunikasi Visual, Fakultas Seni dan Desain Universitas Kristen Petra. Siwalankerto 121-131.

Ibrahim, 2015. Metodologi Penelitian Kualitatif. Bandung: Alfabeta

Kaelan. Filsafat bahasa semiotika dan hermeneutika. Yogyakarta: Paradigma.

Minhal, Abu.Perintah Untuk Saling Menolong dalam Mewujudkan Kebaikan Dan Ketakwaan. Artikel pada Media Islam Salafiyyah, AhlussunnahwalJama'ah, dalam situs https://almanhaj.or.id/ (diakses pada 6 april 2018, 09.00)

Morissan. 2010.Periklanan: komunikasi Pemasaran Terpadu. Jakarta, Prenadamedia Group.

Natanael, Agung. 2017. Dominasi Telkomsel Kuasai Pasar Seluler, berita pada velidnews.com, pada situs https://www.validnews.id/DominasiTelkomsel-Kuasai-Pasar-Seluler-fcx, (diakses pada 6 April 2018, 08.40)

Nurnanengsi. 2016.

RepresenrasiKonsepCantikDalamIKla

nTelevisi (Analisis Semiotika Dalam Iklan Pelembab Wajah Fair \& Lovely Versi Gita Virga). Makassar: Fakultas Dakwah dan Komunikasi Universitas Islam Negeri Alauddin.

Putro, Rino, Andana. 2018. Makna Motivasi Dalam Iklan Air Mineral Aqua Verdi "1 Untuk 10 di Youtube" (AnalisisSemiotika Ferdinand De Saussure). Jogjakarta: Fakultas Ilmu Sosial dan Humaniora Universitas Islam Negri Sunan Kalijaga

Rachmani, Nur. 2015. “Analisis Semiotka Iklan Ades Versi "Langkah Kecil Memberikan Perubahan" Dalam Menyikapi Pesan Tersembunyi Tentang Kepedulian Lingkungan Hidup”. eJournal Ilmu Komunikasi,3, (2):432-446.

Sobur, Alex. 2013. Semiotika Komunikasi. Cetakan Kelima Bandung: PT RemajaRosdakarya

Sobur, Alex. 2014. Ensikopedia Komunikasi J$O$, cetakan pertama, Bandung: Remaja Rosdakarya.

Sobur, Alex. 2014. Ensikopedia Komunikasi $P-Z$, cetakan pertama Bandung: Remaja Rosdakarya.

Soemanagara,Rd. 2012. Strategi Marketing Communication Konsep Strategi dan Tarapan. Cetakan ketiga, Bandung: Alfabeta.

Susanto, A.B \& Wijanarko, H, 2004. Power Branding: Membangun Merek Unggul dan Organisasi Pendukungnya. Jakarta: Quantum Bisnis dan Manajemen 
Syaamil Qur'an. 2010. Al-Qur'an Tajwid dan Terjemahannya. Kementrian Agama Republik Indonesia

Tamburaka, Apriadi. 2013. Literasi Media: Cerdas Bermedia Khalayak Media Massa. Ed 1. Jakarta, Rajawali Pers.

Wibowo,Indiawan, Seto Wahyu. 2013. Semiotika Komunikasi Aplikasi Praktis Bagi Penelitian dan Skripsi Komunikasi.edisi kedua. Jakarta: Penerbit Mitra Wacana Media

Widyatama, Rendra.2009. Pengantar Periklanan, cet 6, Yogyakarta, Pustaka Book Publisher.

Yusuf, Oik. 2017. 4G Telkomsel Bakal Lebih Kencang, Smartphone Pelanggan Support atau Tidak?, berita pada kompas.com, pada situs https://tekno.kompas.com/read/2017/1 0/24/11010007/4g-telkomsel-bakallebih-kencang-smartphone-pelanggansupport-atau-tidak (diakses pada 6 April 2018, 08.50)

\section{Internet}

https://id.m.wikipedia. Org>wiki>4G, (diakses pada 6 April 2018, 08.45)

https://id.wikipedia.org/wiki/Belas_kasihan(di akses pada 25 Februari 2019, pukul $15.05 \mathrm{WIB})$

https://id.wikipedia.org/wiki/Dedikasi(diakses pada 26 Februari 2019, pukul 00.18)

https://kbbi.kemdigbud.go.id/entri/iklan, diakses pada 6 April 2016, 16.30)

https://kbbi.web.id/berani(diakses pada 25 Februari 2019, pukul 22.25 WIB)

https://kbbi.web.id/juang(diakses pada 25 Februari 2019, pukul 21.15 WIB)

https://kbbi.web.id/korban(diakses pada 25 Februari 2019, pukul 23.45)

https://kbbi.web.id/niat (diakses pada 4 Februari 2019, pukul 22. 10 WIB)

https://kbbi.web.id/peduli(diakses pada 25 Februari 2019, pukul 14.58 WIB)

https://kbbi.web.id/sigap (diakses pada 25 Februari 2019, pukul 23.15 WIB)

https://kbbi.web.id/sungguh(diakses pada 25 Februari 2019, pukul 14.20 WIB)

https://kbbi.web.id/tekad(diakses pada 4 Februari 2019, pukul 22. 10 WIB) diakses pada 25 Februari 2019, pukul $14.13 \mathrm{WIB})$ https://kioslambang.wordpress.com (diakses pada 14 Desember 2018, pukul 22.03)

https://pakarkomunikasi.com/teori-semiotikaroland-barthes (diakses pada 8 April 2018 pukul 13.34 WIB)

https://tekno.kompas .com, pada 24 Okt 2017, 11.01, (diakses pada 6 April 2018, 08.50)

https://www.telkom.co.id/servlet/tk/about/id_I D/stocklanding/profil-dan-riwayatsingkat.html (diaksestanggal: 12 Desember 2018, pukul 23.15 WIB)

https://www.telkomsel.com/about-us/our-story (diakses pada 12 Desember 2018, pukul 23.42 WIB)

https://www.youtube.com/watch?v=76BBh2kI tXg, (diakses pada 20 April 2018, 11.07)

https://www.youtube.com/watch?v=bwp6Ttya IC8, (diakses pada 6 April 2018, 09.15)

https://www.zonareferensi.com/pengertiantanggung-jawab (diakses pada 25 Februari 2019, pukul 21.43 WIB) 

p-ISSN: 2502-0935 e-ISSN: 2615-6423 